\title{
British Book Illustration of the 1900-1910s: Sources of Inspiration
}

\author{
Dmitry Lebedev ${ }^{1, *}$
}

\begin{abstract}
${ }^{1}$ State Institute for Art Studies (SIAS), Department of Modern and Contemporary Western Art, Moscow, Russia *Corresponding author.Email: dllebedev@yandex.ru
\end{abstract}

\begin{abstract}
A huge number of illustrators appeared in the beginning of $\mathrm{XX}$ century in Great Britain, first of all in London, who worked on the design of wonderful gift-books. The most outstanding of them were Arthur Rackham (1867-1939), Edmund Dulac (1882-1953), brothers Charles Robinson (1870-1937) and William Heath Robinson (1872-1944), as well as brothers Charles Maurice Detmold (1883-1908) and Edward Julius Detmold (1883-1957). In addition to these artists, more than twenty more graphics were engaged in illustrating various novels, short stories, plays and fairy tales in England in this historical period, but their achievements are either less visible or are the result of imitating the abovementioned illustrators, which makes them secondary to the leaders of this direction.

The peculiarity of book illustration of this period is the high level of technical training of graphic artists who studied on the best examples of Victorian art, numerous references in their work to the styles of past epochs, as well as focusing mainly on classical, or fairy tale literature. All of them are unique in their own way, and therefore there is a special interest in identifying common sources of influence on these masters, to determine the universal stylistic features of their work on the basis of the key subjects of fiction illustrated by them, as well as their classification within the era in all these categories.
\end{abstract}

Keywords: book illustration, book design, graphic, gift-books, limited editions, British art, Edwardian era, art nouveau, Arthur Rackham, Edmund Dulac, William Heath Robinson

\section{INTRODUCTION}

Book graphics in Europe and the United States at the end of the 19 th - early 20 th century is often called "the golden age of illustration", which means the time when the mastery of illustration reached the highest point of its development and quality. English illustrators, especially active between the 1870-s and the 1890-s - Walter Crane, Kate Greenaway, and Randolph Caldecott (the most prominent masters of children's book illustration of their time) are considered to be the pioneers of this process. Becoming idols and inspirers, these artists opened the way for many young illustrators who were busy at the turn of the 19th -20 th centuries.

The work of Edwardian illustrators, which is the important part of "the golden age of illustration", became such a significant phenomenon due to a number of factors:

- Rapid development of the printing industry, which led to the possibility of making photomechanical reproductions from the original illustrations and, in this regard, to the growth of publishers and magazines interested in permanent cooperation with illustrators;

- High level of training in graphic arts in English art schools of the late $19^{\text {th }}$ - early $20^{\text {th }}$ century;

- Edwardian Illustrator's passion for the art of various countries and historical periods;

- The opportunity to earn lots of money in the field of book graphics (this point is a consequence of all the previous ones).

Book graphics of the Edwardian period were the result of all the above factors, but it is impossible to discuss its originality without carefully looking at the previous and closely related graphics of the 1890s also known as "fin de siècle", when not colour, but blackand-white illustration reached the heights of its existence.

W. Crane, K. Greenaway and R. Caldecott got famous for their work on colour children's books and became the primary sources for the art of Beatrix Potter. Even more famous throughout the world, the symbol of English graphics in the 1890-s - Aubrey Beardsley - was the idol of black-and-white illustration, 
aesthetically directed not at children, but at adults, and moreover - the intellectuals of his time. Along with Beardsley in the 1890s, Charles Ricketts (painter and graphic artist, founder of the publishing house "Vale Press") and Laurence Housman (writer and Illustrator, a friend of Beardsley) came to the fore. All three of them relied in part on the exquisitely designed editions of William Morris's "Kelmscott Press", stylized upon the medieval manuscripts; Japanese engraving, which were particularly popular in those years; and the work of the Pre-Raphaelites - mainly through the paintings and graphic compositions of Morris's friend, Edward Burne-Jones.

So without Morris, Burne-Jones, Beardsley, Ricketts, and Houseman (and more than a dozen other lesser-known but also prominent black-and-white graphic artists, like Robert Anning Bell, Hugh Thomson, Henry Justice Ford, etc.), the world would not have seen the Edwardian illustrators, many of whom became followers of these masters in one way or another. And if it were not for the new advances in photomechanical printing, which made it possible to present illustrations not only in colour (which in itself was an innovation), but also with gradation of tones (which actually equated the skill of illustration to painting), we would today consider Edwardian graphics only as fading echoes of the fin de siècle art traditions. Art historian Simon Houfe cleverly compared the perception of this technical revolution with the challenges in the field of cinematography in the late 1920-s "from the silents to the talkies" [1] - not all the graphics accepted the new reality and took the path of colour illustration, as not all the actors left silent movies in 1930-s. However, the high competition that arose between illustrators of the Edwardian era due to the emergence of a new type of so-called deluxe gift-books, gave the masters an incentive to create masterpieces within their profession.

\section{EDWARDIAN GIFT-BOOKS}

Gift-books of the Edwardian era were usually issued in two formats:

- a limited edition was issued with the Illustrator's autograph and usually consisted of 250-500 numbered copies:

- a less expensive trade publication that looked less exquisitely designed, was usually smaller and did not include an autograph, but the text and number of illustrations were identical.

Both formats were intended to play the role of highquality exquisite souvenirs, often presented at Christmas to intelligent and rich London families. Subsequently, they became an integral part of their era, one of its symbols: "Together with a Lutyens house, a Jekyll garden or Daimler car, they [illustrated gift- books] were tokens of Edwardian 'refinement'..." [2]. These editions (most often containing famous classic or children's literature) were not just books intended for reading, but unique leather-bound portfolios of illustrators popular in these years who worked on their design, decoration and those illustrations inside. These editions (most often containing famous classic or children's literature) were not just books intended for reading, but unique leather-bound portfolios of illustrators popular in these years who worked on their design as a whole thing. Outstanding in their quality, and sometimes inventiveness of their author, black-andwhite drawings of various shapes, vignettes, screensavers, endings and letters were scattered throughout the text, as in the $1890 \mathrm{~s}$, but the real spectacle for which such publications were bought were dozens of watercolours printed using a photomechanical reproduction process on thick paper. Such illustrations were protected by tracing paper and attached to plain sheets of dark green, gray or other shading colour, and inserted manually as an appendix to the book after the text (rarely spread throughout the book). So such gift-books, in essence, were divided into two parts - the text with black-and-white drawings and the album part, consisting of most often a number of twenty to fifty colour illustrations, demonstrating the plot of the book with a fine sense of graphic line, and as well showing the outstanding skill of the artist as a colourist. The style of most of these illustrations was dictated by the time - according to the exact remark of the researcher John Russell Taylor, graphic artists of the Edwardian era "...all bear the marks of art nouveau in the details of their forms and compositions, though none can be said to adhere to it wholeheartedly" [3].

Thus, the key source of income, and at the same time the main artistic asset of the Edwardian period illustrators were the cycles of their drawings made for luxury gift editions. In the mid-1900s, the leading London publishers in this field were Heinemann and Hodder and Stoughton - they competed with each other and started to collaborate with the most promising illustrators of their time (A. Rackham and E. Dulac, respectively) to illustrate books published by them every year around Christmas. At the same time, these masters began to sell actively their original illustrations through intermediaries, the key of which was the Leicester gallery, which collaborated with many watercolourists of the Edwardian era and their publishers, who sometimes owned the rights to the original drawings.

\section{ARTHUR RACKHAM AND EDMUND DULAC}

The most desirable Illustrator of the Edwardian era was Arthur Rackham (1867-1939). This master began his career in the $1880 \mathrm{~s}$, occasionally working for various magazines as a caricaturist. In the 1890s, book graphics came to the first place in his creative activity, 
and by 1900 , he was already a recognized Illustrator of his time, securing this title thanks to drawings for "Tales of the brothers Grimm" (1900). However, the real fame came to Rackham a few years later, in 1905, after the publication of "Rip van Winkle" by Washington Irving with fifty colour illustrations by the artist - this book is considered as a showpiece of gift editions of the Edwardian era. It was a light leatherbound limited edition decorated with a small elegant drawing in the art nouveau style, depicting the main character of the fairy tale, surrounded by ivy. Rackham's illustrations completely immerse the reader in the atmosphere of an American village, and then in the world of strange mysterious creatures of the nearby mountains. Here Rackham often uses his favorite move - the anthropomorphization of nature. This feature of Rackham's work haunts him throughout his life, so it is usually easy to distinguish his work from the drawings of other illustrators of the first half of the XX century. So in the illustration "Mutually relieving one another they clambered up a narrow gully" (Fig. 1) the covert presented by the artist in an exceptionally gloomy atmosphere, which is the harbinger of the protagonist's fate, and some trees seem to transform into terrifying ancient creatures with distorted grotesque faces - all done with extreme attention to the smallest detail.

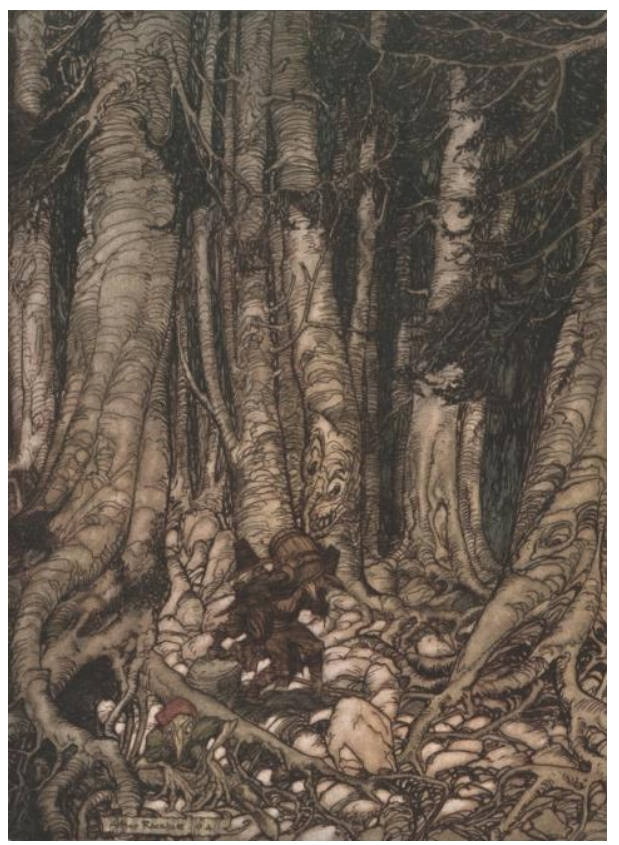

Fig. 1. Rackham A. Mutually relieving one another they clambered up a narrow gully. 1904

The evolution of Rackham's style is already noticeable in the 1906 illustrations for "Peter Pan in Kensington gardens" by James Matthew Barrie. One of the best watercolours of this cycle "There now arose a mighty storm, and he was tossed this way and that" (Fig. 2) is attractive for its dynamics (which is achieved primarily by the arc-shaped compositional structure of the work). This picture shows the hero of the story trying to break through the raging water element to reach the cherished shores of Kensington garden. The illustration is important in terms of its stylistic features: the impending waves in Rackham's interpretation are obviously inspired by engravings by Japanese masters of the Edo period, in particular Katsushika Hokusai (1760-1849) and Utagawa Hiroshige (1797-1858).

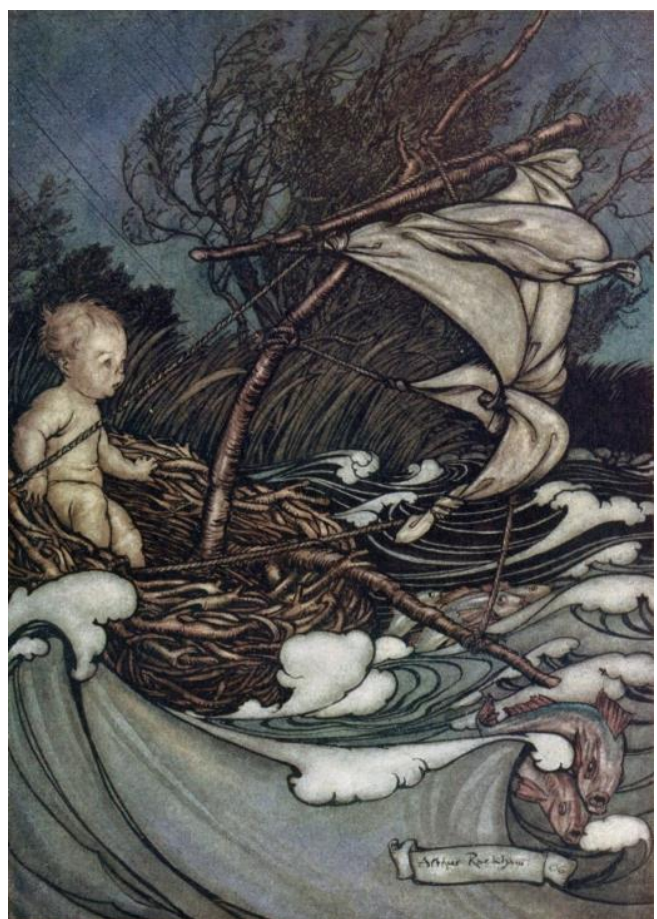

Fig. 2. Rackham A. There now arose a mighty storm, and he was tossed this way and that. 1906

A few years later, in 1909, in the illustration "Soon she was lost to sight in the Danube" (Fig. 3) to "Undine" by Friedrich de La Motte Fouque, Rackham again resorted to a similar interpretation of storm waves [4]. Furthermore, the composition of one of the illustrations to "Undine" (meaning the image "Little niece", said Kühleborn, "forget not that I am here with thee as a guide") was based on specific source - the famous engraving by Albrecht Dürer "Knight, Death and the Devil" (1513). The vignette from the top of the title page of this edition is the logical consequence of Rackham's study of rhythmic ornamental images made by O. Beardsley for "Le Morte d'Arthur" in 1894. 


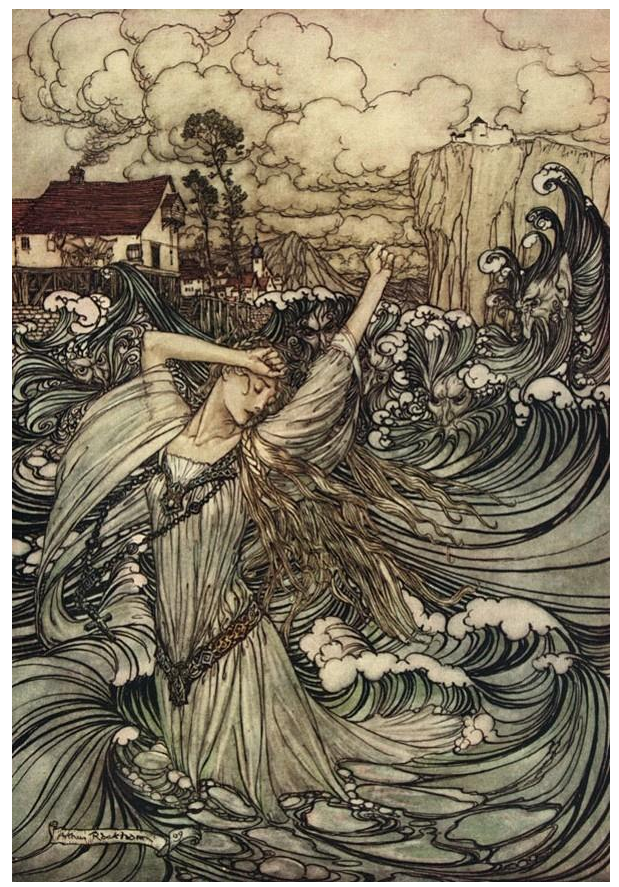

Fig. 3. Rackham A. Soon she was lost to sight in the Danube. 1909

Rackham's further work is very diverse. In the 1917 drawings for the "Novel of king Arthur and his knights of the round table", he reinterprets the design of $\mathrm{O}$. Beardsley to the publication of "Le Morte d'Arthur". In one of the images called "How Arthur drew Excalibur for the first time" (Fig. 4) he resorts to knowledge of the painting by Paolo Uccello "Niccolò Mauruzi da Tolentino at the Battle of San Romano" (about 14381440). In the 1921 illustrations for "Comus" by John Milton he recalls images of beautiful female characters from the paintings of Sandro Botticelli, and in the same years he pays attention to the Persian miniature, which was reflected in the design of Shakespeare's "The Tempest" in 1926. Then, in the late 1920s, he took on a unique project - the creation of a handwritten manuscript on a "Midsummer night's dream", and here the influence of the marginalia of medieval manuscripts is evident. Rackham lived an incredibly productive life, giving the world several thousands of illustrations, and died five days after the start of the Second World War.

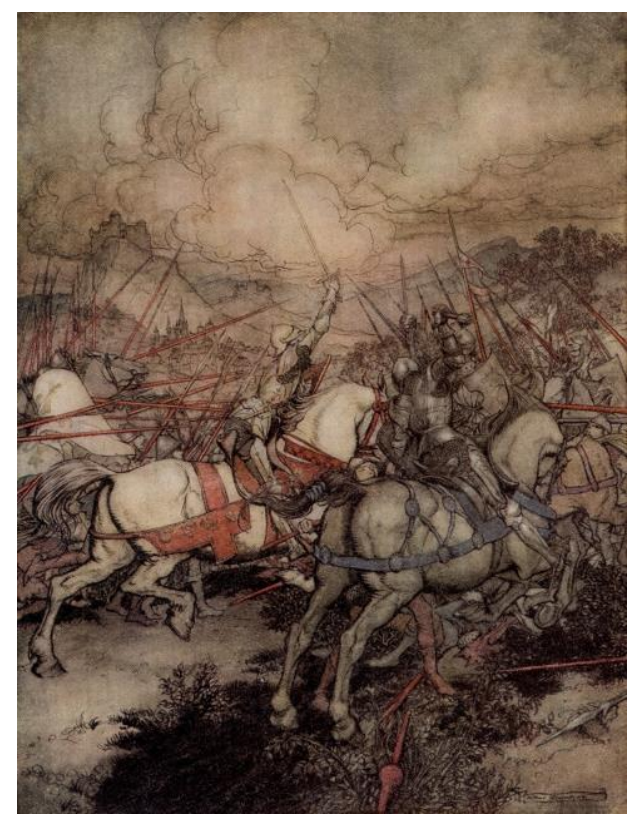

Fig. 4. Rackham A. How Arthur drew Excalibur for the first time. 1917

Another prominent Edwardian illustrator and chief rival to Rackham was his younger contemporary Edmund Dulac (1882-1953). In 1907, when Rackham was working on a series of illustrations for "Alice in Wonderland" that were controversially received by the public, "Stories from the Arabian Nights" was published with illustrations by E. Dulac.

Born in the city of Toulouse, Dulac studied art through the prism of French art trends of the turn of the century, the main of which were symbolism and art nouveau. Like the representatives of these movements, Dulac was genuinely inspired by the art of the East, which was fuelled by his native uncle's job, who imported various inexpensive objects from the East, including works of art from Japan and China [5], and instilled in him a love to Orientalism. In addition, Dulac systematically studied English culture and art, which was also reflected in his stylistics. The combination of these interests of the artist brought an incredible charm to the illustrations for the "Stories from the Arabian Nights" of 1907, which he made shortly after moving to London. The publication received rave reviews from critics - a brilliant translation of the famous stories, made by the popular writer and graphic artist Laurence Housman, was perfectly combined with mysterious, not lacking in humor, bright colour illustrations of Dulac. In fact, it was thanks to this publication that Dulac's talent was noticed by London society, as the newspapers wrote about him: "nothing so dainty in colour and, with certain exceptions, in workmanship has been seen for a long time" [6]. 


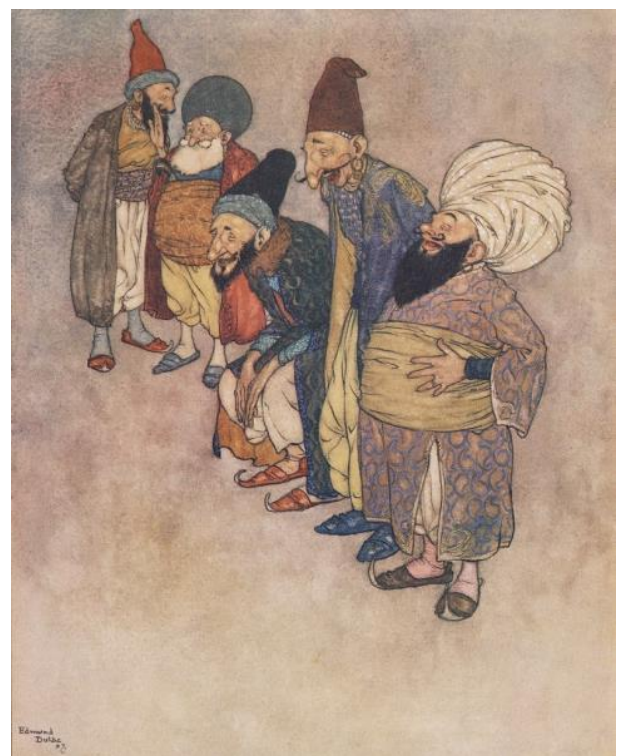

Fig. 5. Dulac E. All the courtiers burst out laughing. 1907

Among Dulac's many illustrations for this collection of oriental tales, some stand out. The drawing "All the courtiers burst out laughing" (Fig. 5) reveals two features that were inherent to Dulac in his future works - the ability to convey grotesquely ironic plots through a caricature look at the characters and a certain interest in ethnic costume, with no actual background shown on the watercolour. Some other illustrations, on the contrary, reflect the artist's interest in the landscape genre. It is curious that all peculiarities of architecture or fashion of the East (which look very convincing in his drawings) are taken from various exhibits, which he either collected himself or saw in other people's collections and museums, as he personally, throughout his life, never visited any of the Asian countries. For the series of illustrations for "Stories from the Arabian Nights" in 1907, Dulac used mainly soft blue colour with many tonal transitions - a typical example is the watercolour "She and her companion arrived at the city of Harran" [7].

Dulac returned to the theme of Arabic fairy tales twice more - in 1913, creating four drawings for the story of "Princess Badoura" and in 1914, illustrating a few more parables from the Arabian Nights. In both cases, graphic interest in Japanese engraving prevailed, particularly in the art of Suzuki Harunobu (1724-1770). It was reflected in the interpretation of space in the illustration "She ran ahead and rushed into the arms of Kamaralzaman" (Fig. 6) and Katsushiki Hokusai attention to his sea landscapes influenced the interpretation of the sea wave from Dulac's drawing "The Episode of the Whale". The second source of inspiration for the 1914 edition was the Persian miniature - the artist simplified the compositions of the drawings and completely distorted the perspective, as well as alternating bright colours in contrast to give the drawings an eastern flavor.

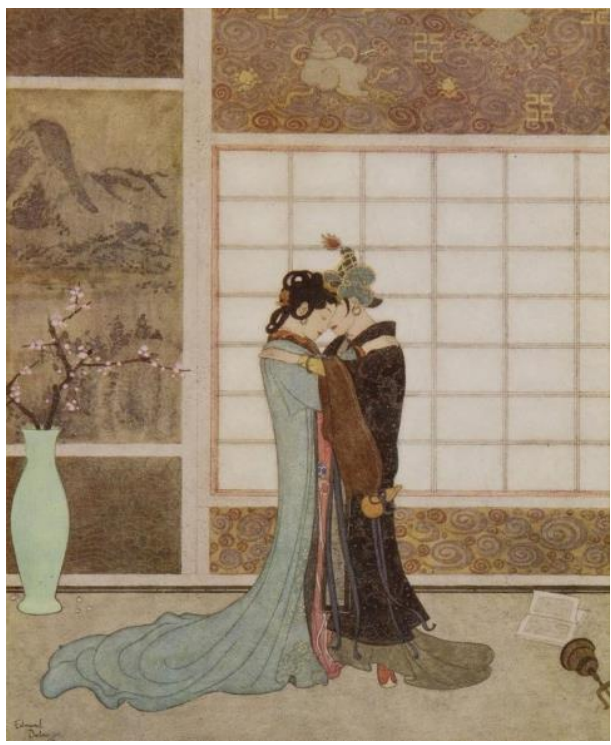

Fig. 6. Dulac E. She ran ahead and rushed into the arms of Kamaralzaman. 1913

After the publication of the "Stories from the Arabian Nights" in 1907, the rivalry between Rackham and Dulac began. It reached its climax the following year, 1908, when publishers Heinemann and Hodder and Stoughton gave London several luxury editions of William Shakespeare's plays, the first of which were "A Midsummer Night's Dream" with illustrations by Rackham and "The Tempest" with drawings by Dulac. The critics wrote about Rackham's visual version of Shakespeare: "...the Rackham Shakespeare will find himself on another shelf among the masterpieces of modern illustrative art" [8] and about Dulac - "He [Dulac] makes his vision of Prospero's enchanted island uncommonly interesting from first to last" [9]. 


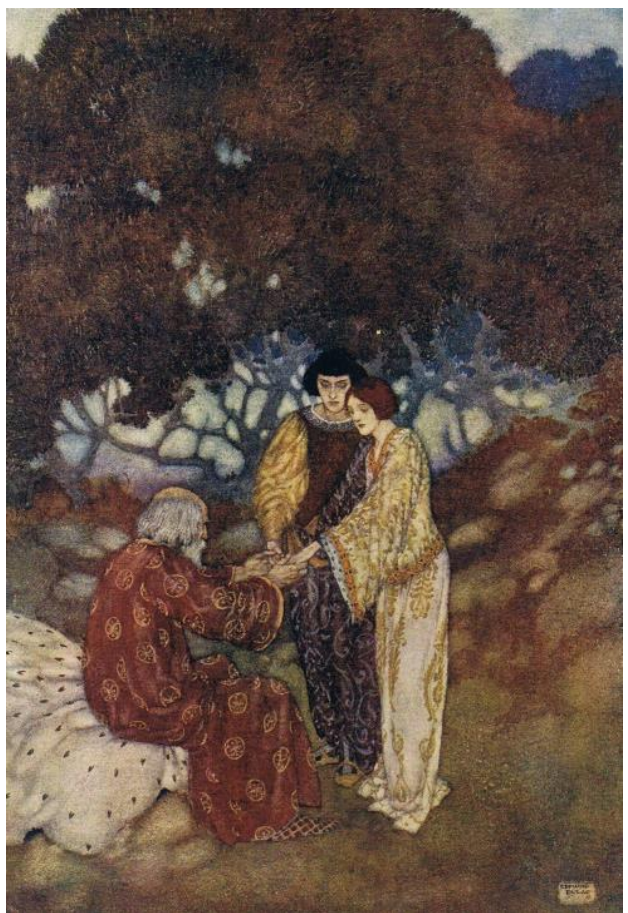

Fig. 7. Dulac E. Give me your hands: Let grief and sorrow still embrace his heart That does not wish you joy. 1908.

In "The Tempest", Dulac, as in the Arabian nights earlier, paid close attention to the costumes of the characters - only now they were luxuriously coloured, ornamented tunics and dresses (an example is the drawing "Give me your hands: Let grief and sorrow still embrace his heart That does not wish you joy" (Fig. 7)). The symbolic meaning definitely plays a key role in the illustration "We are such stuff as dreams are made on", which shows the very fabric of the universe in dark blue tones, close to the art of French and Belgian symbolists, in particular Jean Delville. Interest in symbolism as a trend in art is further captured by Dulac's illustrations for the 1912 collection of poems by Edgar Allan Poe: the artist in "Ulalume" (Fig. 8) refers to Arnold Böcklin and his painting "Isle of the Dead", while the watercolour "The Haunted Palace" (Fig. 9) is stylistically reminiscent of the wondrous worlds from the canvases of Jan Toorop. The stylistic manner of J. Toorop at the turn of the 19th-20th centuries also greatly influenced the work of artists and graphic artists of the Glasgow School. The theme of the incomprehensible mighty nature is revealed in a kind of Dulac's ommage to the famous painting "Wanderer over the Sea of Fog" by Caspar David Friedrich, made for the poem "Alone".

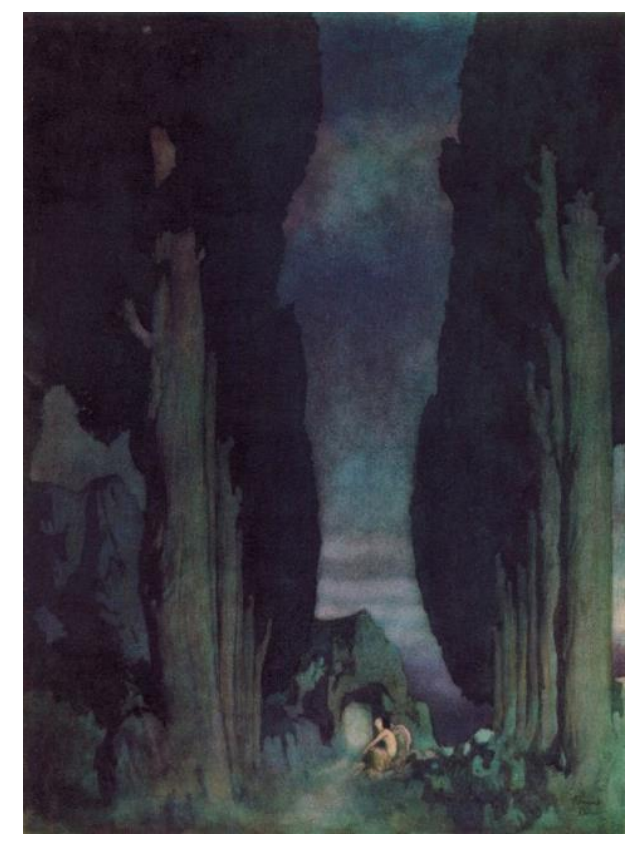

Fig. 8. Dulac E. Ulalume. 1912.

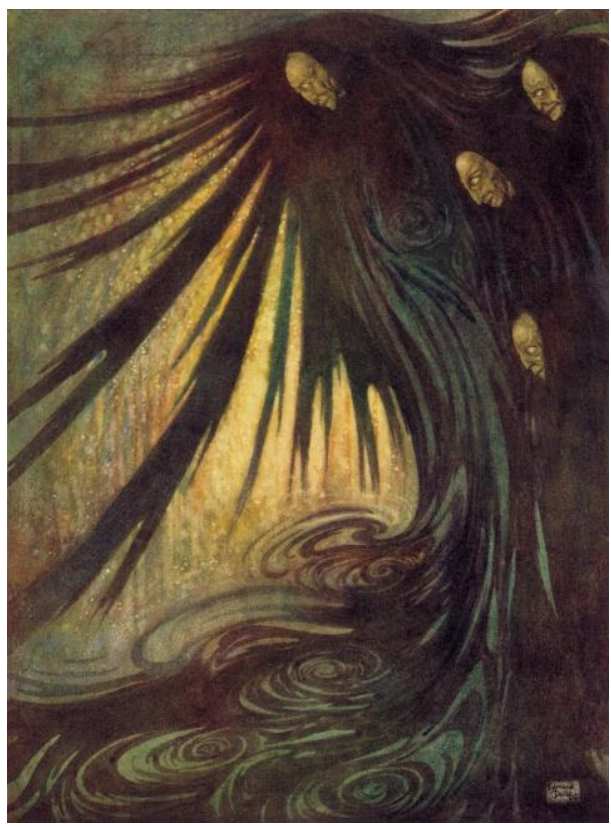

Fig. 9. Dulac E. The Haunted Palace. 1912

In an original project, the illustrations for the "Tales of the Allied Countries" of 1916, Dulac demonstrated his ability to build his watercolours style on the culture within which a particular story arose.

Previously, this feature was shown in other cycles of his illustrations. For example especially interesting is the reference to the Northern Renaissance painting in one of the illustrations to the "Stories from Hans Andersen" in 1911. The view outside the window in the drawing "She played upon the ringing lute, and sang to 
its tones", as well as its general perspective plan resemble the famous painting by Jan van Eyck "Madonna of Chancellor Rolin" (1436). So, his illustrations for the "Tales of the Allied Countries" seem to "...confirm Dulac's remarkable ability to borrow ethnic elements from history and adapt his style to the country of origin and the time of the events of that history" [10]. The collection contained several fairy tales from different peoples, and along with England, Ireland, France, Belgium, Italy, Serbia and the Netherlands, the fairy tales of Japan and the Russian Empire were presented here. For Dulac, Russian culture and art were a kind of fusion of Asian and Russian traditions, with a significant bias towards Asia. This was reflected in his illustrations, which were decoratively bright and flat, resembling decorations on the caskets, obviously stylized as Russian lubok and, most likely, as the art of the famous Russian graphic artist Ivan Bilibin (1876-1942). Japan, represented by only one illustration in this collection, looks much more restrained in tone and almost monochrome in the interpretation of Dulac (artist pays special attention to the Japanese type of line and composition). Here again there are associations with Harunobu's work, whose scenes often consisted of paired characters, one of whom visually rose above the other and was turned to him in half a turn.

In the late 1910s, Dulac illustrated "Tanglewood Tales" by Nathaniel Hawthorne, where he used his knowledge of Persian miniature painting and ancient Greek vase decoration to create authentic images of characters and locations (an example is the watercolour "Jason appointed Tiphys to be a helmsman because he was a star-gazer" (Fig. 10).

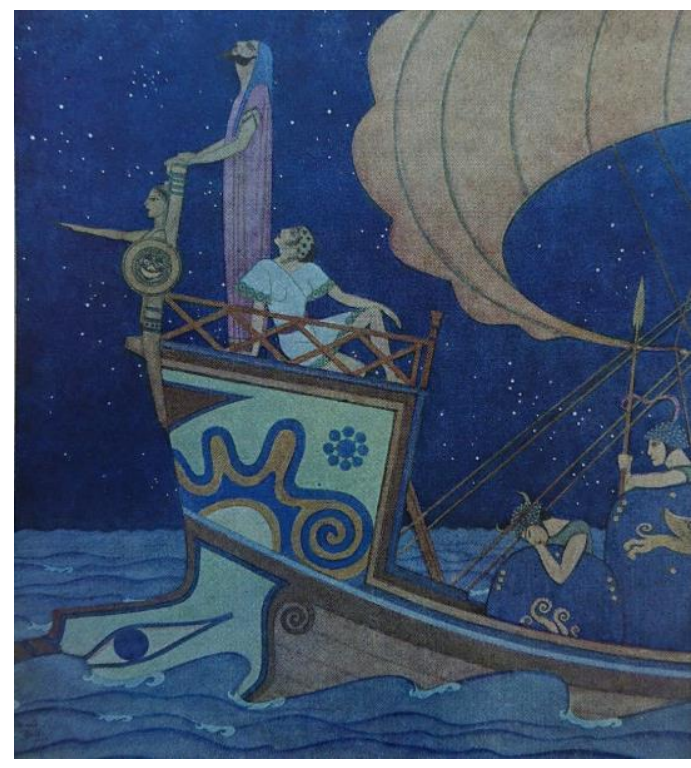

Fig. 10. Dulac E. Jason appointed Tiphys to be a helmsman because he was a star-gazer. 1918
Along with Dulac, in the same years English graphic artist Warwick Goble and Irish illustrator Rene Bull also imbued with the charm of the East, often resorting to orientalist themes in their drawings.

Although several dozen illustrators worked in Edwardian London, Rackham and Dulac became best known among them: "These two artists [A. Rackham and E. Dulac] dominated the fashionable gift-book market" [11]. Newspapers of the late 1900s compared them all the time, stimulating competition between the illustrators. Rackham was even known to subscribe to newspapers in which Dulac was mentioned [12]. Also curious was the poem in The Observer's December 20, 1908 issue, which was an advertisement for Christmas gifts, where a small part was devoted to books with illustrations of Rackham and Dulac:

\section{"Here you buy (suppose you lack 'em) \\ Volumes beautified by Rackham, \\ Or, again (what very few lack), \\ Volumes beautified by Dulac!" [13]}

Rackham and Dulac were the followers of Victorian fairytale painting traditions and masters not only in the field of book illustration, but also in caricature drawing, as evidenced by their numerous grotesque pictures in various magazines of the late 19th and early 20th century. Of course, they knew their predecessors in this field, and above all the cartoonists of Punch magazine: Richard Doyle, John Tenniel, Charles Samuel Keene, George Du Maurier, Phil May and other masters of Victorian England.

\section{OTHER EDWARDIAN ILLUSTRATORS}

Nevertheless, there were other prominent masters whose creative work cannot be avoided in this article. The Charles and William Heath Robinson brothers confidently kept up with the times, working, among other things, on the design of gift editions. And if Charles brilliantly illustrated children's books back in the second half of the $1890 \mathrm{~s}$, his brother William achieved success in the next decade in the field of color illustration.

Thanks to his black and white fairy-tale illustrations in the mid-1890s, the young C. Robinson was awarded an article in The Studio, where two years earlier also honored Beardsley. In the drawings of Charles in the 1890s, the thickness of the graphic line defined the first, second and third plan of the drawing, thus creating an illusory depth. The incredible detail of space, especially in the field of architectural details, was able to charm publishers of the turn of the century, due to which the artist began to receive numerous orders (a typical example of illustration of this period can be considered a picture "Life in Fairyland"). However, his further 
illustrations, with rare exceptions, became more and more standardized, simplified, and his coloured drawings for 1907 edition of "Alice in Wonderland" lost out ingenuity and detail (which was previously the hallmark of C. Robinson) to the illustrations of A. Rackham, made to the same literary masterpiece the same year.

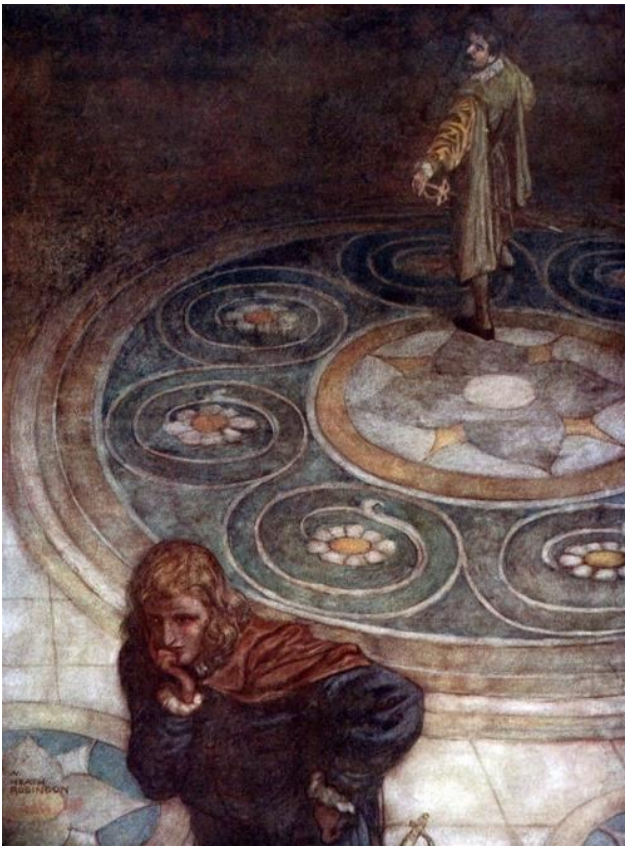

Fig. 11. Robinson W.H. Yet, a barful strife! Whoe'er I woo, myself would be his wife. 1908

The creative work of his brother William Heath Robinson in the gift-book market coincides with the mid-1900s and early 1910s, as with Rackham and Dulac. His 1908 illustrations for Shakespeare's "Twelfth Night" deserve a place among the best examples of book graphics of its time. The overall impression of the whole cycle, according to the precise remark of art historian James Hamilton, ties our perception with famous painters - Antoine Watteau and William Turner, as well as the less famous Scottish master John Pettie [14]. In the author's opinion, the American-English painter Edwin Austin Abbey should be added to these outstanding personalities. The charming effect of these illustrations comes from the angle chosen by their creator - the point of view in some of the drawings (in particular, the following: "Yet, a barful strife! Whoe'er I woo, myself would be his wife" (Fig. 11), "Practising behaviour to his own shadow" and "Pray God, he keep his oath!"). The elaborate costumes of the characters and the decorative elements of the scenery in which they are depicted (such as the watercolour "Yet you will be hanged for being long absent") hint at the theatricality of the entire action (Fig. 12). In this way, it is as if a reader is watching the play based on Shakespeare's work, rather than flipping through the pages of the illustrated play. On this subject, the researcher of W.H. Robinson's work Geoffrey Beare wrote: "...the high viewpoints chosen for some of them [illustrations] give one the feeling of looking down from a box or the upper circle in an old fashioned theatre" [15]. It's worth mentioning that in the illustration, "If he was twenty Sir John Falstaffs, he shall not abuse Robert Shallow, Esquire!" (Fig. 13) by Hugh Thomson to the 1910 edition of "The Merry Wives of Windsor", the artist, as well as E. Dulac and W.H. Robinson before him, when illustrating other Shakespeare plays, pays particular attention to the costumes of characters. In 1914, W.H. Robinson illustrated "A Midsummer Night's Dream", where black-and-white and coloured drawings were the culmination of the traditions embedded in book graphics by Beardsley on the one hand, and Rackham on the other. With such a design, this edition summed up the entire era of Edwardian luxury gift-books. Beginning in the mid-1910s, William Heath Robinson began to work more and more on cartoon images, dedicated to the absurd reading of the achievements of technological progress or current world events (starting with World War I). It was this activity that later made him famous throughout the world.

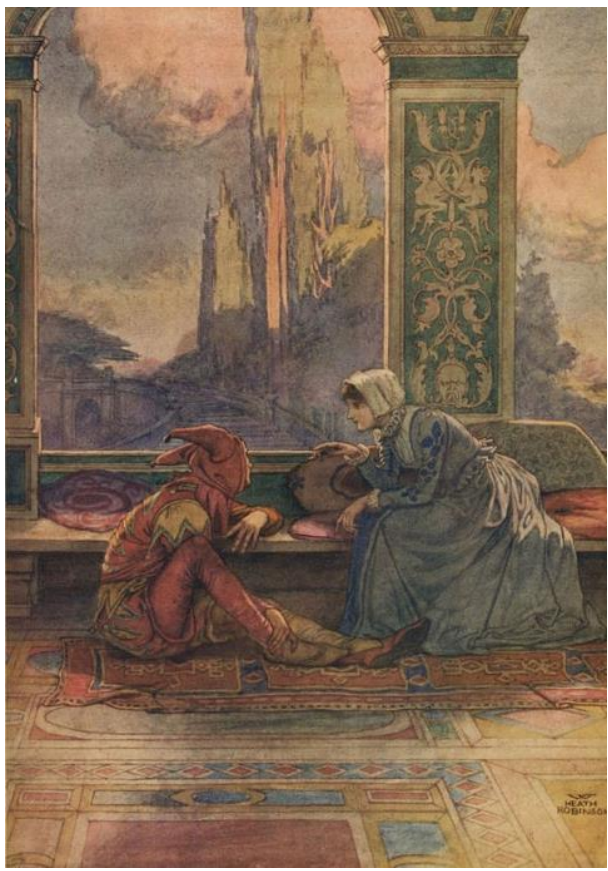

Fig. 12. Robinson W.H. Yet you will be hanged for being long absent. 1908 


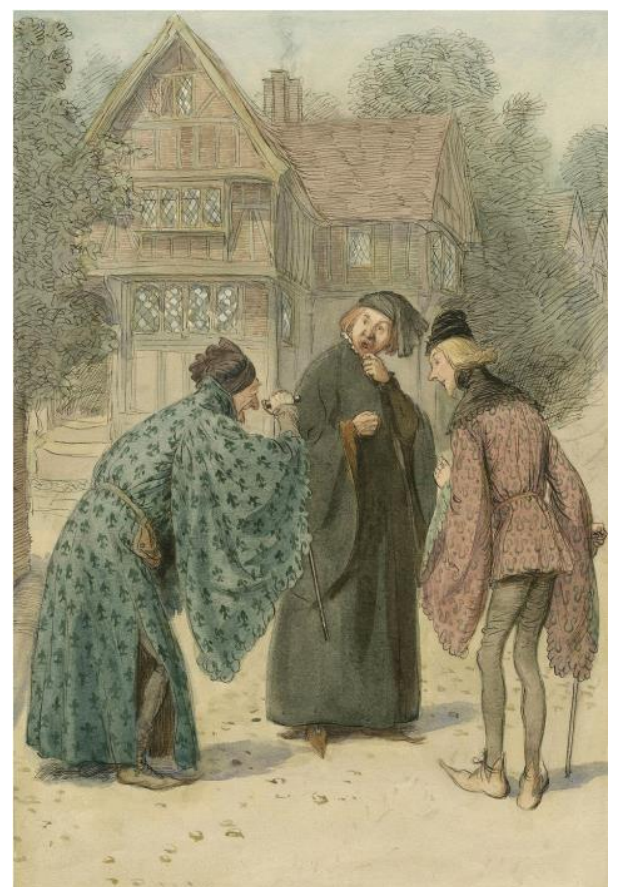

Fig. 13. Thomson H. If he was twenty Sir John Falstaffs, he shall not abuse Robert Shallow, Esquire! 1910.

The masters, who will be remembered first of all thanks to one, but certainly unique edition, were twin brothers Edward Julius and Charles Maurice Detmold. Since childhood they were fond of drawing animals, and in 1903 they illustrated Rudyard Kipling's "The Jungle Book" (the brothers made 16 watercolors for the publishing house "MacMillan") - this edition was a masterpiece of Edwardian era. The most attractive of their joint illustrations from this series, which clearly became a real "magnum opus" of both brothers "Shere khan in the jungle" (Fig. 14). All the qualities developed by the animal painters over the years of training and enthusiasm for the art of the East were displayed here: the influence of Japanese engraving, its planar elongated space, original composition, anatomical knowledge, detailed elaboration. Even interest in symbolic interpretation of literary material a hint at the sanctity of the main character, presented by the artists in the form of a sun's halo above his head (perhaps, allusion to the idea that Mowgli is not affected by civilization, which is essentially a kingdom of vice). Researcher Rodney Engen wrote about their unique vision of the natural world with the following words: "...using their acute understanding of the forces of nature, they created the mythology and harshness of the natural world" [16]. Further achievements of the brothers cannot be compared with this success, taking into account also the fact that just five years after the publication in 1908 there happened an accident Charles Detmold died. Subsequently, the career of the surviving Edward gradually waned, and never rose to its former level.

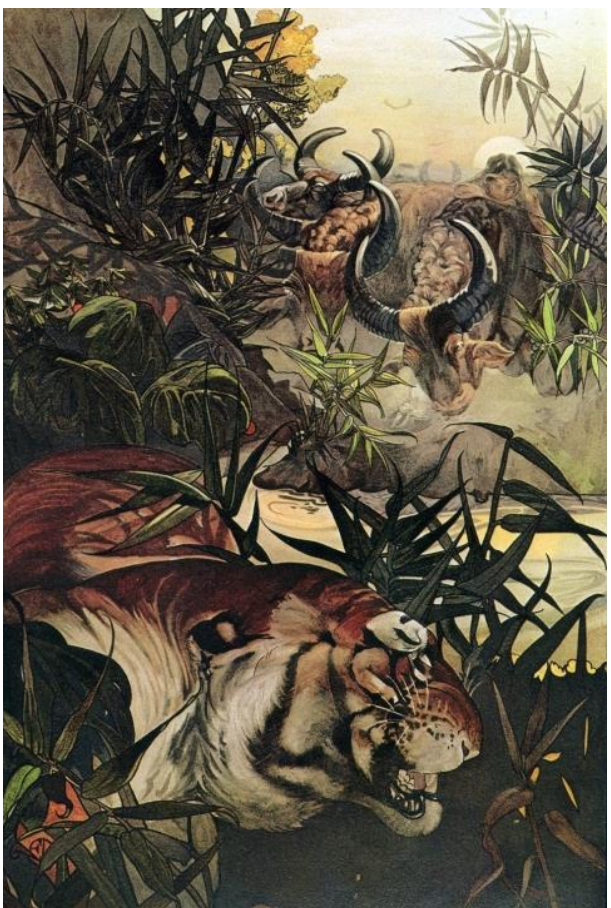

Fig. 14. Detmold E.J. and C.M. Shere khan in the jungle. 1903

In the 1910s, Willie Pogany (who illustrated novels as early as the late $1900 \mathrm{~s}$, but succeeded in the next decade, with the influence of Alpons Mucha in his work), Kay Nielsen, Charles Folkard and Thomas Mackenzie, who continued the traditions of their predecessors, joined the abovementioned representatives of the golden age of Illustration who worked in London. Also worth mentioning is the artist Eleanor Fortescue-Brickdale, who was called the last representative of the Pre-Raphaelite artistic tradition. Her works are a tribute to that famous brotherhood, their compositional and colouristic views. In addition, during the same period, there were a number of masters whose distinctive feature was to follow the traditions of Aubrey Beardsley's black and white style. The most outstanding of them in the 1900s and 1910s were Jessie Marion King (a prominent representative of Glasgow School), Sidney Sime and Harry Clarke.

\section{CONCLUSION}

The graphics mentioned in the text became a whole cultural layer, thanks to which the skill of book illustration at the end of the 19th - first two decades of the 20th century reached the level of painting, both in popularity and quality. The stylistic diversity of these illustrators varied greatly, although it was generally associated with art nouveau culture. The masters drew inspiration mostly from the same sources as their predecessors - the graphics of the Victorian period but they interpreted this material differently. Among these sources of inspiration are Orientalism (Japanese 
etching of the Edo period and Persian miniature), the design of Western European medieval manuscripts (including Celtic ornamentation), German art of the 15th-16th centuries, Pre-Raphaelite art, Aubrey Beardsley drawings, theater sets and costumes. There were also specific preferences that were typical for the particular illustrators: ancient Greek vase design, paintings by prominent artists such as Caspar David Friedrich, William Turner and Antoine Watteau, and even Russian lubok.

Thematically, on the contrary, they were mostly similar to each other, and turned to fairy-tale literature ("Arabian nights", H.C. Andersen, Brothers Grimm etc.), as well as to English classics (here the most relevant was W. Shakespeare). Both themes are widely revealed in the works of the most famous graphic artists of this period.

Thus, the illustrators of the Edwardian era were not just faceless cogs, but unique personalities with individual creative characteristics, whose knowledge of art history was deep, and allowed them to freely interpret a particular literary work through its visual reading, to become not just a tool in the hands of the writer, but real co-authors of the books they illustrated.

\section{References}

[1] S. Houfe, "Fin de Siecle. The Illustrators of the Nineties", London: Barrie and Jenkins, 1992, p. 168.

[2] M. Felmingham, "The Illustrated Gift Book. 1880-1930", Hampshire, Wildwood House, 1989, p. 5.

[3] J.R. Taylor, "The Art Nouveau Book in Britain", New York, Taplinger Publishing Co., 1980, p. 142.

[4] See: D.L. Lebedev, "Illustrations of English artists of children's books of the turn of XIX-XX centuries in Russian prerevolutionary publications: influence and parallels" in: "Children's Readings: Studies in Children's Literature", Saint Petersburg, 2019, no. 2 (16), pp. 320-340.

[5] See: C. White, "Edmund Dulac", London, Studio Vista, 1976, p. 11.

[6] The Manchester Guardian. 05.12.1907. P. 6.

[7] See: D.L. Lebedev, "Edmund Dulac's Book Graphics and the Problem of Orientalism in British Illustration of Edwardian Era and the Second Decade of XXth Century" in: "Proceedings of the 3rd International Conference on Art Studies: Science, Experience, Education (ICASSEE 2019), Paris, Atlantis Press, 2019, p. 801-807.

[8] The Observer. 29.11.1908. P. 4.

[9] The Manchester Guardian. 23.11.1908. P. 4.

[10] C. White, "Edmund Dulac", London, Studio Vista, 1976, p. 77.

[11] D. McKitterick, "The Book in Britain", vol. VI. 1830-1914, Cambridge, Cambridge University Press, 2009, p. 409.

[12] J. Hamilton, "Arthur Rackham. A Life with Illustration", London, "Pavilion Books Limited", 1990, p. 97.

[13] The Observer. 20.12.1908. P. 8.

[14] J. Hamilton, "William Heath Robinson", London, Pavilion Books Limited, 1995, p. 52.
[15] G.C. Beare, "The illustrations of W. Heath Robinson", London, Werner Shaw LTD, 1983, p. 29.

[16] R. Engen, "The Age of Enchantment. Beardsley, Dulac and their Contemporaries 1890-1930", London, Scala Publishers Ltd., 2007, p. 34. 